\title{
Class, complicity, and capitalist ambition in Dhaka's elite enclaves
}

\author{
Paul Robert Gilbert
}

\begin{abstract}
This article draws on ethnographic work carried out in London and Dhaka as part of a multisited project exploring the production of investment opportunities for (predominantly British) companies in Bangladesh. Focusing on the ready-made garments (RMG) sector in the run-up to, and in the wake of, the 2013 Rana Plaza factory collapse, I trace aid-funded attempts to improve Bangladesh's investment climate and engagements with these initiatives by brokers seeking to "rebrand" Bangladesh as an investment destination and by RMG factory-owning businesspeople based in Dhaka. Writing against the "postcritical turn," I suggest that responding to the explicit recognition by business elites of their own complicity in the exploitation of garment workers provides an entry point for a critical account of private sector development that enhances, not curtails, ethnographic understanding.
\end{abstract}

Keywords: Bangladesh, complicity, critique, development, investment climate, Rana Plaza

\section{Introduction: Postcritical anthropology and private sector development}

In 2015, the Bangladesh Board of Investment's Roadshow UK was hosted in Canary Wharf, a private estate in the former Docklands that emerged as London's second financial district during the 1990s. The event was presented as being "for investors and corporate heads who want to explore the opportunities of a frontier market like Bangladesh. The country offers untapped opportunities in a plethora of sectors which ensures handsome return, with smooth option for repatriation of equity and divi- dend." Bangladesh, attendees were assured, is the investment friendly regime in South Asia. With this roadshow, the Bangladesh Board of Investment was reproducing a long-standing script according to which investment promotion agencies emphasize a "textbook outline of features known to be attractive to foreign export-oriented investors" (Klak and Myers 1997: 137), albeit with a twist. The treatment of Bangladesh by the Board of Investment as a frontier market reflects an explicit effort on the part of the International Finance Corporation (IFC) the private sector arm of the World Bank Group (WBG) - from the 1990s onward to "rebrand" 
developing nations as attractive locations for foreign investment.

In part, this has worked by reinvigorating narratives about opportunities for "pioneers" to profit from "exotic" locations that animated extractive enterprise in the days of the Empire (Lai 2006: 632; Sidaway and Pryke 2000: 195). Formally, however, the IFC now defines frontier markets as the poorest 82 countries supported by the WBG's International Development Association and makes it clear that "investment climate" reform is a key concern as far as frontier markets are concerned. Of the many "rule of law" (Merry et al. 2015) and "competitiveness" (Davies 2014: 108-147) indices now produced as decision-making tools for foreign direct investors (and yardsticks for policy makers), the WBG's Doing Business rankings have done the most to forge, out of a tangle of legal and economic indicators, the "investment climate" as something tangible that can be visibly "enhanced" through legal reforms that make it easier to (among other things) start a company, dismiss workers, or enforce a contract (PerryKessaris 2011: 402).

Analysts at JPMorgan and Goldman Sachs, meanwhile, have included Bangladesh as a member of the "Frontier Five" or "Next-11," respectively. These putative successors to the BRICSthe grouping of Brazil, Russia, India, China, and South Africa propagated by the Goldman Sachs analyst Jim O'Neill in 2001 with a view to breaking down divisions between "developed" and "developing" countries in the imagined geographies of financial institutions seeking highgrowth opportunities (Wansleben 2013)-are assembled in part based on the size of their "economically active populations." In Bangladesh's case, the youthful population and gross domestic product (GDP) growth driven by the readymade garments (RMG) industry are determined to be sufficient to offset the "political risk" associated with duopolistic party politics (e.g., Mowat and Gordon 2007: 6). For the Dhakabased fund managers concerned with the national reputation or "brand" (see below), who reproduce the JPMorgan and Goldman Sachs classifications on their websites and promotional materials, what matters is not only the size and youthfulness of the workforce, but also their cheap labor costs. Even in a less-than-ideal investment climate, when labor costs are so low there is profit to be made for those with the right speculative disposition (see Appadurai 2012).

Most workers in the RMG sector, rendered by analysts of Bangladesh's investment climate as cheap unit labor costs or members of an attractive economically active population, are young women-often rural-urban migrants from landless families. Their attempts to navigate new urban employment opportunities, persistent patriarchal family relations, workplace harassment, and union formation have received considerable ethnographic attention-both before (Feldman 2009; Kabeer 1991; Kibria 1995; Rock 2003) and after the 2013 Rana Plaza factory collapse (Chowdhury 2017a, 2017b; Dey and Basak 2017). By comparison, the factory owners whose fortunes have been made through the emergence of Bangladesh's multibillion-dollar RMG export industry and the persistence of unsafe and exploitative working environments have been largely absent from the ethnographic literature. This by no means reflects a lack of concern about class or elites in the anthropological literature on inequality and development in Bangladesh. The postindependence political settlement in which political leaders in Dhaka entered relationships of patronage with landowners (jotedars), who were able in turn to guarantee voter turnout among the landless workers who constitute their clientele, has been well documented (e.g., Adnan 2013; Lewis 2017), as has the emergence of alliances between elites in the NGO sector and transnational corporations accumulating rural land in the name of development (e.g., Ahasan and Gardner 2016; Gardner 2012; Rahman 1999).

The relative lack of attention given to factory owners perhaps reflects a broader trend in anthropological work on business elites and development professionals: a reluctance to engage with questions of class, exploitation, and capitalism, particularly when this may lead to critical 
depictions of one's ethnographic subjects (see Gilbert and Sklair, this issue). The anthropologists of development who describe themselves as nonnormative (Mosse and Lewis 2006), postcritical (Yarrow and Venkatesan 2012; see also Jensen 2014), and acritical (Jensen and Winthereik 2013; Winthereik and Jensen 2017) have drawn on Bruno Latour's writings (esp. Latour 2004; see Jensen 2014: 338; Mosse 2013: 232) to develop a program of research oriented toward tracing out the contingent and often surprising practices and alignment of interests that the translation of development policy into practice involves. This program is set against older work in the anthropology of development that depicted development professionals as distant others "at once powerful and ignorant" and the development industry as the "kind of closed, bulletproof system beloved as a target of critique" (Winthereik and Jensen 2017: 252-262). To treat development as the unfolding of a "concealed power" (Mosse and Lewis 2006: 15; see also Mosse 2013: 229; Yarrow and Venkatesan 2012: 7) vested in the uniform and unreflexive interests of transnational corporations and development institutions is, for these authors, to abandon ethnographic sensitivity in favor of taking comfort in one's own pessimistic-if not ethnocentric-critical convictions (Yarrow and Venkatesan 2012: 5-12; see also Holbraad 2017). In short, it is argued that "critical engagement often seems to curtail understanding" (Yarrow 2008: 441).

In this article, I examine the frictions generated when aid-funded investment climate reform programs, nation-branding exercises, and the interests of factory-owning elites were brought into awkward alignment in the run-up to and immediate aftermath of the Rana Plaza disaster. My analysis is set against frameworks that treat nation-branding and investment-promotion activities, investment climate reform, and the cooperation of local capitalists with globalizing ambitions as reflecting the operations of a more or less unified capitalist class in charge of the process of globalization (cf. Sklair 2000: 73; Sklair and Struna 2013: 748). To this extent, I share something of the methodological and analytical approach adopted by postcritical anthropologists of development: my aim is certainly not to retreat from ethnography to invoke the operation of some concealed power or to depict investment promotion and investment climate reform as the operation of a closed, bulletproof system centered on the WBG. However, if it is said by postcritical scholars that critique moves us further away from actors' own understandings and practices by invoking predetermined sources of explanation (capitalism, empire, development), then it can also be argued that postcritical perspectives render political-economic relations based on exploitation and domination invisible, even when these are made manifest by actors' own narratives and practices.

Recent work on class (Carrier and Kalb 2015) and the generation of capitalist life projects (Bear et al. 2015) has made room for an examination of the uneven accumulation of wealth and exploitation of labor that does not reduce the study of social reproduction within a configuration of antagonistic interdependence merely to a language of class "position" or "system" (Kalb 2015: 14-17). A desire to reject the language of class or exploitation wholesale because of a tendency on the part of some authors to subordinate ethnographic description to prepackaged models of capitalism (or use the capitalist world system as the "context" through which ethnographic findings can be rendered sensible) does make a certain amount of sense (see Marcus 1989). But-as is the case here-when factory owners in Dhaka make it explicit that their own life projects depend on exploitation of the cheap unit labor costs that make Bangladesh such an attractive "frontier" market, it seems both reasonable and necessary that their reflections be granted the capacity to "put in motion" (Latour 2005: 48) my broader ethnographic inquiry. The possibility that attending to actors' own narratives and practices might put in motion inquiries that require that class-based exploitation be invoked has perhaps escaped proponents of the postcritical turn because of an overarching concern that overdeter- 
mined, denunciatory critiques of development as the operation of concealed power blind us to "the collaboration and complicity (or duplicity) of marginal actors/institutions in development" (Mosse and Lewis 2006: 4, emphasis added). I argue here that hewing closer to one's ethnographic materials may invite critique, or at least the language of class-based exploitation, and that invoking such exploitation does not necessitate a retreat to broad, structural narratives or self-satisfied acts of denunciation.

In this article, therefore, I adopt what Fiona Probyn-Rapsey (2007) describes as "complicity as a methodology." Unlike George Marcus (2001: 521), I do not see complicity as a mode of ethnographic engagement that demands postcritical, collaborative inquiry (see also Gilbert and Sklair, this issue). Instead, I argue that although ethnographic research rests upon complicity - or the generation of knowledge through more or less intimate relationships-there is no requirement that the knowledge thus produced be nonnormative or acritical. Knowledge of the ambitions harbored by factory-owning businesspeople in Bangladesh may be derived from ethnographic complicity, but this does not mean it is necessarily opposed to, or curtailed by, a critical orientation that arises from that very encounter. Complicity can both "disable oppositional conviction-oriented critique because of the complex interrelationships it brings about," and "drive oppositional critique" by prompting recognition of responsibilities to those beyond our immediate ethnographic subjects (ProbynRapsey 2007: 65, 79).

In the remainder of this article, I first draw on fieldwork carried out in London and introduce aspects of the investment climate reform initiatives that the United Kingdom has been promoting in Bangladesh and elsewhere as part of its post-2010 turn toward the private sector as the primary engine of development (Mawdsley 2015). I focus in particular on the "Better Regulation" agenda, which, in line with the WBG's Doing Business rankings, promotes the relaxation and privatization of business regulation as a pathway to better development. In the second section, I draw on fieldwork carried out in Dhaka in 2013, shortly after the Rana Plaza factory collapse, in which the kinds of regulatory relaxation encouraged by the Better Regulation agenda was found to be complicit. Here, I examine the attempts that financiers made to act as brokers, that is, to create opportunities for profit and national development by "rebranding" Bangladesh in the wake of Rana Plaza. In the final section before the conclusion, I introduce a group of businesspeople whom I met initially as part of an aid-funded investment climate reform project and describe their attempts to resist efforts that donors made to transform Bangladesh intro an easier place (for foreign investors) to do business. These same businesspeople who would resist or divert the aims of aid-funded investment climate reform projects were, nonetheless, explicitly and self-consciously complicit in the exploitation of RMG factory workers. I conclude by reflecting on complicity as a methodology and by challenging the viability of a nonnormative or postcritical anthropology of development when researchers may find themselves complicit, through their ongoing relationships and writing, with those who profit from the exploitation of socially distant others.

\section{Investment climate reform and the business of aid}

Bangladesh has long figured as an "aid laboratory" (Hossain 2017) for international donors and development professionals, with the women's empowerment and microcredit programs of large Bangladeshi NGOs like Proshika, BRAC, and Grameen receiving significant donor funds and frequently being held up for international emulation. And this emulation has come in spite of oft-articulated domestic concerns about the operating practices of these organizations and their relationships with both multinational corporations and political elites (Lewis 2011: 113-125). What has been less well studied is the emergence of several "investment climate reform” programs funded by the UK's Depart- 
ment for International Development (DFID), the United States Agency for International Development (USAID), and the IFC.

While early international business scholars bemoaned the fact that executives expressed their uncertainty about the prospect of doing business in newly independent postcolonial jurisdictions through vague synthetic terms such as "poor investment climate" (Kobrin 1982: 44-46, 173), the "investment climate" has now taken on a tangible, manageable aspect thanks to a proliferation of investment climate ratings and rankings (Perry-Kessaris 2011). The Bangladeshi business press eagerly awaits the annual release of rankings compiled by the WBG's Doing Business survey and the World Economic Forum's Global Competitiveness Report, seeking evidence of whether current policy agendas are proving successful (see Gilbert 2015). And success is, of course, measured by movement up the rankings. For countries to set explicit targets for "moving up" the Doing Business rankings is fairly common, since the regulatory criteria that require alteration in order to do so (time and effort to start a new business, access to electricity, paying taxes, getting credit, enforcing contracts in the courts) are well known (Besley 2015: 100-101; Hoyland et al. 2012; Schueth 2011).

Most studies of investment climate rankings have emphasized the extent to which they produce "state extraterritoriality" (Schueth 2011: 53) or promote private authority in global governance (Davis et al. 2012; Sunn Bush 2017), as ideal models of (pro-private sector, anti-union) regulation generated outside the state are implemented through consultancy-enabled fast policy. With few exceptions (e.g., Schueth 2011), ethnographic examinations of the implementation of "investment climate reform" are largely absent. In my own fieldwork, which I carried out between 2012 and 2015, I was concerned with how aid-funded investment climate reform in Bangladesh intersected with attempts by officials (and entrepreneurs) to "rebrand" Bangladesh as a frontier investment location and take advantage of Bangladesh's inclusion in groupings like the "Frontier Five" and "Next-11" by financial analysts in the City of London. In particular, I was interested in a range of initiatives that were partly funded by DFID as part of the turn back toward the private sector as the locus of developmental change (see Mawdsley 2015). Of these many initiatives-which included DFID/IFC-backed efforts to improve arbitration capacity and "spread the rule of law in a very American way" in order to enhance the attractiveness of Bangladesh to foreign investors (Gilbert 2018)-I focus here on the activities of the UK's Better Regulation Delivery Office (BRDO).

My fieldwork began in London at the offices of what was then the Department for Business, Innovation and Skills (BIS) in late 2012 at a launch even for the BRDO. The BRDO had been founded in 2012 as part of the Coalition government's intensification of New Labour's move to recast business regulators as partners rather than as enforcers (Tombs 2016). The director of the BRDO declared their ambition not only to treat businesses as the "customer of regulation," but also to scale the BRDO up from being a body concerned with local government in the United Kingdom to one providing an "international model" for better regulation. This ambition was reflected in the invited presence of government officials and WBG representatives from a range of countries in which DFID operates, including Bangladesh. BRDO and BIS officials spoke of the important role that regulators could play by working with businesses to generate "prosperity" around the world.

Officials from the OECD and the WBG took to the podium in order to cast excessive regulation as the primary problem impeding global prosperity via reference to Mohamed Bouazizi, the Tunisian street vendor whose self-immolation catalyzed the Arab Spring and was a response to his persecution by state officials. While the oppression exercised by state officials in numerous contexts is certainly not without (often devastating) consequences, there is nonetheless something troubling about a UK agency promoting to the members of the Bangladesh Investment Climate Fund who were in atten- 
dance, a pathway toward development that involves enhancing the "ease of doing business" by recasting regulators as "enablers" of businesses. After all, before the Rana Plaza factory collapse in 2013 (less than six months after this launch event) Bangladesh had already witnessed significant loss of life in dozens of factory fires and collapses that were due, at least in part, to overburdened inspectorates (Muhammad 2011: 25).

\section{Rebranding Bangladesh}

Relocating my fieldwork to Dhaka in mid2013, I made contact with officials working on DFID- and USAID-funded investment climate reform projects, as well as with those working with the government and various Chambers of Commerce to "rebrand" Bangladesh as a place in which to do business-a particular concern in the immediate aftermath of the Rana Plaza disaster. One of the first working in this area, a leading figure in various efforts to rebrand Bangladesh and promote foreign direct investment through various traveling roadshows, was Ijaz. ${ }^{2}$ A British Bangladeshi who emphasized that he was "actually from London," Ijaz split his time between Dhaka and London for periods of three to four weeks at a time. He had set up a brokerage house and financial analysis firm in Dhaka after spending 18 years working for global banks in the City of London, and his clients now included both financial houses in Bangladesh and large "frontier market"-focused funds based in London and New York such as BlackRock and Templeton (the "Frontier Five" and "Next-11" statuses of Bangladesh were displayed prominently on his firm's promotional material). When we met in 2013, shortly after the Rana Plaza factory collapse, he was busy working on the RMG 10-point plan that was part of the garment industry's response to the crisis, which had advocated government financing for RMG reforms and the inspection and reclassification of factories. Ijaz's primary concern, however, was the "Bangladesh perception deficit" and the fact that Bangladesh lacked "positive brand associations"- other than, in his view, Muhammad Yunus of the Grameen Bank.

The Dhaka Chambers of Commerce were failing in their country branding strategy, Ijaz argued. This was especially so in comparison to the "proactive, focused, very structured longterm engagement by "India Inc." that brought together government, the private sector, and the Chambers of Commerce:

And the example I like to use is at the World Economic Forum, 2006 or 2007, the "Incredible India" launch, the Indian delegation put pashminas and iPods in every delegate's room, really influential people. And they flew in Indian chefs and Bollywood dancers. The Indian chambers are proactively sending out positive information. Bangladesh is very poor at doing that.

Ijaz's concerns about Bangladesh's country branding failures or "perception deficit" seemed to share something with the aid-funded investment climate reform projects outlined above. To the extent that they are about improving a country's position on any one of a number of rankings, targeted reforms designed to enhance the "ease of doing business" are also about "rebranding." The difference here, perhaps, is that Ijaz was more concerned with discovering the discursive strategies required to convincingly present Bangladesh as already being a desirable location for investment.

Ijaz explained how he drew from Simon Anholt's work on nation branding, which emphasizes the need for tourist boards, investment promotion agencies, cultural institutes, exporters, and politicians to work together on a longterm nation branding strategy, in order to seek "permission" (2006: 6) from consumers of exports, or potential investors. Ultimately, for Anholt a "'brand' is really just a metaphor for how countries can compete more effectively in the modern age" (23), even if it has to be "mined" out of national history and chime with "some- 
thing fundamentally true about the place and its people" (75). Hence, for Ijaz even Amartya Sen's writings (e.g., Dreze and Sen 2013), which were drawing attention at the time to Bangladesh "outperforming" India across a range of poverty indicators, could contribute to nation-branding and investment-promotion strategy.

Brand Bangladesh might have been outperforming India on development indicators, but it could also have been "undercutting" China when it came to RMG production costs. This, Ijaz, explained, was "similar to the Walmart effect; you know, Western consumers go to Walmart because it's the cheapest. Bangladesh is the Walmart of suppliers; it's the lowest cost. It's an inherent hedge - a real grab for value." Ijaz also challenged the tendency for Bangladesh to be depicted as a difficult or risky place to do business in investment climate rankings and political risk reports (e.g., PRS Group 2011):

Many of the people who think Bangladesh is a risky place don't know the country. Yes, it's difficult-there are problems with the legal structure, corporate governance-but this is true in many emerging markets. The fact of the matter is that Bangladesh can outperform its peers.

Bangladesh might be lacking when it comes to nation-branding strategy and the challenges of projecting a competitive identity. But, as a national economy known by its growth rate and the cost of labor, Bangladesh could compete as a destination for foreign direct investment, providing, as it did, an "inherent hedge" due to the extremely low cost of production for RMG firms (and, as many Board of Investment officials were keen to point out, having no "correlation" with the postcrisis slump affecting much of the Global North).

Ijaz's attempt to rebrand Bangladesh, the Board of Investment officials' presenting Bangladesh as a land of "untapped opportunities," and aid-funded regulatory reform projects carried out with an eye on improving Doing Business rankings might seem to reflect the coordination of interests among the bureaucratic and financial fractions of a "transnational capitalist class" (e.g., Sklair 2000). Though I maintain the importance of a critical perspective, and reject the notion that critique and ethnography are necessarily opposed modes of knowledge production, it is not my intention here to invoke the operation of some concealed power, overarching capitalist logic, or hegemonic development apparatus. Ijaz is, perhaps, an archetypal development broker, concerned with making meaning (rebranding Bangladesh) rather than taking on a specific functional role in an overarching system of domination (Mosse and Lewis 2006: 20).

Brokers have in the past been treated as morally troubling precisely because they appear to make political-economic structures dissolve into the agency of morally ambiguous individuals (James 2011). But it is equally not my intention to simply reinvigorate the mode of critique according to which brokers appear as "parasites" (Mosse and Lewis 2006: 12). Instead, I hope to show that the RMG factory owners who profit directly from exporting the fruits of cheap "Walmart" labor in fact have ambitions and attitudes toward investment climate reform and rebranding Bangladesh that diverge significantly from those held by brokers like Ijaz. There may not be an overarching logic of capital or a coordinated set of interests lurking behind the actions of brokers like Ijaz or indeed the RMG factory owners, but their own social reproduction is self-consciously complicit in the exploitation of RMG workers' labor.

\section{Capitalist ambition and complicity in the "Republic of Gulshan"}

Ijaz narrated his work in Bangladesh as a logical "next step" following his success in the City of London's banking industry, and was concerned with "opening up" the Bangladeshi frontier through a combination of rebranding and acting as a broker for a variety of frontier market funds. This was not entirely the case for the businesspeople whom I met through an aid-funded 
investment climate reform project later in 2013. Rather than attempting to convince foreign investors that Bangladesh was less risky than it appeared, these wealthy elites were concerned with staving off the competition that might undermine their ability to reproduce themselves as elites in Gulshan, the enclave in which most of Dhaka's diplomatic residencies, embassies, international clubs, and self-consciously cosmopolitan elites locate themselves. Some of its residents jokingly refer to as the "Republic of Gulshan," and there is a relative ease with which theoretically proscribed commodities can be acquired within the enclave. It remains somewhat insulated from the hortals (collective actions), which opposition politicians often use to shut down or disrupt movement in other parts of the city.

The businesspeople discussed in this section come largely from families who have been based in Dhaka since the British or Pakistani period and who attempt to set themselves off from more recent arrivals to the city through the performance of a specific form of cosmopolitan identity. Many have recently moved into homes and apartments in Gulshan from the increasingly densely populated districts of Dhaka, where their ancestral homes were located. Most have worked, studied, or have second homes outside Bangladesh, and remain unencumbered in their travels by the increasingly punitive financial requirements placed on Bangladeshi citizens seeking visas for the United Kingdom and other jurisdictions. While many of the individuals discussed below have made millions from their RMG factories, and while some have had political aspirations, they do not belong to (and attempt to differentiate themselves from) the small core of "crony capitalists" (Mahmud et al. 2010: 234) who emerged following a spate of privatizations in the 1990s. This wave of denationalization left the ownership of most previously public assets in the hands of, by some estimates, 217 families (Haque 2002) and most bank deposits controlled by a mere 37 families (Nurruzzaman 2004).

Instead, the residents of the Republic of Gulshan who are introduced below attempt to set themselves apart from those businesspeople who are too close to party politics in Bangladeshor what the brother of one of the businesspeople introduced below described as the "lower middle-class" politics of the Awami League and the Bangladesh National Party. They maintain and emphasize cultural links with middle-class bhodrolok (lit. gentleman) culture in Kolkata, and continue to participate in the culture of "club-ability" that lives on in old colonial clubs (long since open to membership from the national elite), as well as the newer international clubs (often only open to those Bangladeshis with dual citizenship). Echoing the process of Ashrafization (Mannan 2002) described elsewhere in Bangladesh, ancestral links to Mughal elites, and parents and grandparents who held significant administrative positions under British rule, were invoked-only half-jokinglyduring social events held by members of this business community. My interest here is not, however, in the transformation of social capital and markers of aesthetic distinction into economic capital (cf. Gardner 2008); it is rather with the exploitation of factory workers that Gulshan-based factory owners rely on for their own social reproduction, and which disappears when a "postcritical" perspective is adopted.

In late 2013, I attended a parliamentary private sector caucus at an independent private sector development think tank that was headed up by a former Bangladeshi diplomat and located in the particularly upscale "Gulshan-2" district. The purpose of this donor-funded event was to survey Dhaka-based business elites on how the business environment or investment climate could be best be reformed through future initiatives. When I had first met Shaheed (a civil servant and academic who also worked at the think tank) earlier that year, he had explained the institution's function with reference to a then-unfolding controversy about bidding for oil and gas exploration rights. Finding the terms that they were offered too restrictive, several oil and gas firms were looking instead to neighboring Myanmar-or at least threatening to unless terms were improved. Shaheed described 
just how they positioned themselves as brokers with contacts in government, the civil service, and the investor community: "If Shell came and said, 'We need this thing to be resolved,' we can't just say to government, 'This is what Shell wants.' But let us see if we have a program that we can fit your agenda in and with that we can go to the government."

The programs to which he was referring were "multistakeholder" aid-funded trade facilitation or investment climate reform programs that the think tank regularly hosted. Several such programs were held before the 2012/2013 bidding round for oil and gas exploration rights finally revealed itself to be somewhat abortive (largely because several multinationals rejected government demands for restrictions on gas exports and for requirements to sell to Bangladesh at low prices). Once again, this institutional brokerage might appear to resonate with frameworks such as Leslie Sklair's (2000) approach to the "transnational capitalist class," according to which a corporate faction works together with globalizing bureaucrats to ensure that all business interests, but especially those of foreign investors, are catered to in the hope that (perhaps) their investments may enhance the national interest. But, as I show below, there is not nearly so much alignment in Bangladesh between the ambitions of bureaucrats promoting investment climate reform and the local capitalist elites, whose positions are nonetheless dependent on the exploitation of labor.

The parliamentary private sector caucus meeting was similarly supported by a variety of investment climate reform initiatives funded by DFID and USAID and was designed to prepare for the possibility of a change of government in early 2014 (the scheduled elections, however, never took place). As the discussions among the attendees unfolded, Sabur, an aspirant Member of Parliament and preeminent garment manufacturer, questioned whether Bangladesh should in fact be trying to "compete" for foreign direct investment, as Ijaz (who was known to most in the room) had been suggesting. Faisal, a former diplomat, argued that, yes indeed, it should, cit- ing Bangladesh's ultimate failure to lure oil and gas investors away from Myanmar and Vietnam's ability to increasingly attract RMG investment as reasons for the need to compete. Sabur disagreed vehemently:

Every day when I wake up and read the paper, I have to pinch myself. The nation has a direction, but the government doesn't align. For the last 42 years we have grown well. This is the Bangladesh paradox. ${ }^{3}$ As quality of governance goes down, growth goes up. Maybe we should discourage intervention, if the private sector is doing well without Parliament? The last 42 years, the growth I am talking about has basically transformed us from an agricultural nation to an industrialist nation. We could do that very well without governance.

Rather than go for foreign direct investment, Sabur suggested that the "low-hanging fruit" of those in the diaspora be turned to in order to fund capitalist development in Bangladesh. Besides, he did not feel that the attempts to rebrand Bangladesh and promote investment through the kind of roadshows that enthused Ijaz would ever serve the interests of the nation, and especially not those of the attendees at this event: "I go to these trade delegations and people don't believe it's a place to invest. Only when they see a white face like Jason's, then they will come. They are not going to be impressed by the Chairman of the Board of Investment."

Jason was the US-born executive of one of the largest multinational investment banks operating in Bangladesh, and he had been a key speaker at several international investor roadshows and summits that Ijaz had helped to promote (including the Board of Investment roadshow introduced at the outset of this article). But Jason's interests were certainly not aligned with the idea of fundamentally transforming Bangladesh and its reputation (as per Ijaz's ambition). When I had spoken to Jason earlier in 2013, he had stated explicitly that "we're not 
here to develop the country; we're here to develop clients and add value." True, the "highly trainable" population was attractive, but ultimately Bangladesh was a "diversification play": "if someone wants to throw 2 percent of their portfolio into Bangladesh risk, they're not making a big statement; it's just going in the soup."

Sabur continued, providing a biographically rooted analysis of the relationship between opportunities for Gulshan-based business elites and investment climate reform that was fundamentally at odds with projects embedded in the Doing Business rankings (cf. Ferguson 2006: 206; Lash 2002: 45):

The highest per capita FDI is in countries where there is no governance at all! Because they can exploit these countries. The statistics show we do not need governance. I'll tell you an anecdote. There was an American guy at Rashed bhai's [a mutual friend of most in attendance] son's birthday. He said if we improved Gulshan traffic, everything would be fixed in this country. I said, "Sorry, it's all difficult in this country, even trying to pay tax." And I said, "Sir, because it is so difficult, it gives us a chance to thrive; if it was so easy, you would have come to exploit us and we wouldn't be able to live in Gulshan!"

At this point, one of the other attendees, a lawyer close to the ruling party whose family also had significant RMG factory holdings (as well as interests in shrimp farming and tea plantations) affirmed, "I agree; there isn't anywhere else I'd like to live in the world."

Toward the end of 2013, I was at a dinner with Sabur, where one of the guests was the head of a small NGO that had been hired by international NGOs concerned with auditing factories in the wake of Rana Plaza-and by multinationals whose garments were produced in the Rana Plaza factory-in order to disseminate compensation. Farah, the NGO leader (whose family also had interests in a number of RMG factories), asked across the table, "Sabur, tell me, have you implemented your 5 percent fund yet?" The question referred to the Bangladesh Labor Law (Amendment) 2013, which demanded that 5 percent of profits be set aside to a worker's welfare fund, and it was one of many piecemeal measures enacted to reform the RGM sector following the Rana Plaza collapse. Sabur's reply, to laughter from those in attendance, was simple: "Of course not! How would I live?!" In this moment, a community of complicity (Steinmuller 2011: 25) came into view, which was propelled by the deliberate irony of Sabur's reply. For Steinmuller, communities of complicity emerge where irony is deployed as part of an effort to create intimate spaces in which shared experience is acknowledged-along with an awareness of the (critical) representations others may produce of that intimate space. The irony here is created because everyone in attendance knows Sabur would still live perfectly well (albeit perhaps not quite so well), were he to implement his 5 percent fund. They know too that such wealth as accumulated by those in attendance with interests in RMG factories depends on the "cheap unit price" of Bangladeshi labor and on the vast profits that are to be made through garment exports-and that this might make them subject to critique by outsiders.

David Mosse has described the dilemma faced by doctoral researchers in anthropology who find themselves pulled between the desire to stay close to one's research participants (and so forego critical distance in analysis), and a temptation to withdraw into abstract frameworks "oriented in broad terms toward leftist political critical commitments and speaking to a largely academic audience" (2015: 135). I would suggest that adopting complicity as a methodology (Probyn-Rapsey 2007) offers an alternative to the putative choice between subordinating analysis to overdetermined political-economic frameworks and deferring to the understandings of your interlocutors-one that is all the more necessary when writing about powerful economic and political actors whose social position explicitly, and by their own (albeit ironic) 
admission depends on exploitation. ProbynRapsey (2007), following Sanders (2002), notes that, while complicity in or "foldedness" into the lives of others may disable critique by dissipating oppositional convictions, it may equally drive oppositional critique by prompting recognition of responsibilities. These responsibilities may be to our ethnographic interlocutors, but they may also extend further. This is especially the case when working with powerful subjects who may themselves be complicit in reconfiguring the terrain of social reproduction for those less powerful. In such instances, adopting a nonnormative or postcritical stance hostile to the language of class and capitalism may curtail understanding, just as postcritical scholars fear critique does (cf. Yarrow 2008).

In his work with Rana Plaza survivors, Rashedur Chowdhury (2017a, 2017b) has been critical of the elite Bangladeshi NGOs (including the celebrated BRAC) for their complicity in the behavior of multinational retailers, whose pursuit of cheap labor and fast lead times had created the conditions for poorly regulated "unofficial" subcontractor factories like those housed in the Rana Plaza complex. By taking on the disbursement of compensation to victims of Rana Plaza and their families, thereby allowing multinational retailers to "subcontract morality" to them (2017b: 943), elite NGOs both provided retailers with legitimacy and contributed to the silencing of the voices of those who frequently received inadequate compensation or support from those same NGOs. Chowdhury's (2017a) potent and emotive ethnographic writing emerges from encounters with Rana Plaza survivors; his "foldedness" into their lives generates a critique of those who have failed the subjects of his writing. Being aware of the exploitation on which the RMG industry depends is itself enough to generate a similar kind of foldedness, or what Sanders (2002) terms responsibility-in-complicity, and my argument here is that such responsibility-in-complicity should not be dissipated when ethnographic work is carried out among elites merely because of a notion that critique is necessarily crude or somehow anti-ethnographic. Indeed, the ironic recognition by elites of their own complicity in the exploitation of others can provide an entry point into ethnography that is as necessarily critical as it is sensitive to context.

\section{Conclusion: Class, critique, and complicity}

My intention during the fieldwork on which this article is based was never to "get the ethnographic goods" on elites (cf. Marcus 1998: 27). Instead, my concern was to trace out the relationship between UK (and multilateral) donorfunded investment climate reform projects and the attempts that the Bangladeshi state and Dhaka-based brokers make to "rebrand" Bangladesh as an investment frontier. The decision to invoke class-like relationships of exploitation and cast a critical gaze on the strategies for social reproduction adopted by factory-owning businesspeople in Gulshan is not motivated by a desire to cast myself in a morally redemptive critical role (cf. Felski 2015: 51; Marcus 2012: 40). Nor do I lay claim to already knowing that investment climate reform is yet another instance of the hegemonic development apparatus playing out, or that business-political elites in Gulshan act as they do because of their class position. Quite the opposite.

There is no machinic development apparatus at play here, but there is a contingent alignment between regulatory agendas adopted by successive UK governments (e.g., BRDO), the attributes of investment climates measured by indices like the Doing Business rankings (which capture the attention of certain policy elites in Dhaka), and the efforts of certain financiers who have positioned themselves as brokers between frontier market investment funds and "Brand Bangladesh.” It is not my intention to impose a rigid language of class position on to my ethnographic subjects in order to "explain away" their behavior. Ijaz and Sabur, for instance, have quite divergent ambitions for the future of Bangladesh and the extent to which foreign inves- 
tors and businesspeople might (or should) be encouraged to operate there in a "reformed" or "rebranded" investment climate. Class-like relations of exploitation-some of which are all too explicit, as in the case of Sabur's reluctance to turn over a fraction of his profits to his workforce-are present and significant, but class is not an external logic that exists outside of Sabur's (or Ijaz's) rooted (or mobile) projects of social reproduction, which take place within specific sets of social relations.

Rather than rehabilitate the form of critique that postcritical scholars take to be their target (and to which perhaps some, but by no means all, avowedly critical scholars subscribe), or retreat into a "traditional critical project that uses (Western) theoretical resources (such as moral philosophy) to judge, undermine or ratify" the lives of others (Gad et al. 2015: 82), I have attempted to work with complicity as a methodological disposition. Marcus's (2001) writing on complicity and ethnography led him toward (noncritical) collaborative engagement with those who are complicit with powerful institutions of social change. I would suggest, however, that Probyn-Rapsey's (2007) approach to complicity as methodology can offer a potent template for ethnographers who wish to maintain an openness to novelty, surprise, and understanding in the field without wishing to foreclose a priori upon the potential for critical writing that may arise from entering into communities of complicity with those whose projects of social reproduction imply the exploitation, precarity, or indebtedness of others. For the anthropology of development, this is perhaps all the more urgent as donor funding increasingly operates through private sector vehicles and initiatives (Lightfoot et al. 2017). It would be a strange anthropology indeed that could independently make space for ethnographies of RMG factory workers, the development professionals working on investment climate reform, brokers seeking to rebrand Bangladesh, and RMG factory owners who contest investment climate reform while profiting from export-oriented investment and cheap labor-but disguise the unstable, exploitative, and antagonistic interdependences that tie their worlds together for fear that critique works against greater understanding.

\section{Acknowledgments}

The research on which this article is based was supported by an ESRC/Sussex DTC $+3 \mathrm{PhD}$ Studentship (2011-2015, \#1093387). I am grateful to Jessie Sklair and the participants in the workshop that gave rise to this theme section; to Dinah Rajak, Katy Gardner, Sahil Dutta, Richard Lane, and Focaal's anonymous reviewers for insightful comments on earlier drafts; and to all those who made the fieldwork on which this article is based possible.

Paul Robert Gilbert is Lecturer in International Development (Anthropology) in the School of Global Studies at the University of Sussex. His doctoral research (Social Anthropology, University of Sussex) explored the role that legal, geological, and financial expertise plays in opening up new frontiers for mineral exploration. $\mathrm{He}$ is currently conducting research on the political risk industry and on speculative investment and corporate harm in the extractive industries.

E-mail:p.gilbert@sussex.ac.uk

\section{Notes}

1. As per the promotional literature circulated before, and available at, the event.

2. As with all names in this article, this name has been altered to preserve anonymity.

3. Here, Sabur was referencing a much-discussed concept in development economics, the "Bangladesh paradox": the putative paradox is that on a number of human development indicators (infant mortality, under-five mortality, maternal mortality, and female literacy and education), Bangladesh outperforms India and Pakistan, despite significantly lower per capita GDP and per capita income. For many commentators, 
this can be accounted for by the post-Liberation establishment of thriving, now global, NGOs like BRAC and Grameen.

\section{References}

Adnan, Shapan. 2013. "Land grabs and primitive accumulation in deltaic Bangladesh: Interactions between neoliberal globalization, state interventions, power relations and peasant resistance." Journal of Peasant Studies 40 (1): 87-128.

Ahasan, Abu, and Katy Gardner. 2016. "Dispossession by 'development': Corporations, elites and NGOs in Bangladesh." South Asia Multidisciplinary Academic Journal 13. doi:0.4000/ samaj.4136.

Anholt, Simon. 2006. Competitive identity: The new brand management for nations, cities and regions. London: Palgrave Macmillan.

Appadurai, Arjun. 2012. "The ghost in the financial machine." Public Culture 23 (3): 517-540.

Bear, Laura, Karen Ho, Anna Tsing, and Sylvia Yanagisako. 2015. "Gens: A feminist manifesto for the study of capitalism." Cultural Anthropology, 30 March. http://www.culanth.org/ fieldsights/652-gens-a-feminist-manifesto-forthe-study-of-capitalism.

Besley, Timothy. 2015. "Law, regulation, and the business climate: The nature and influence of the World Bank Doing Business project." Journal of Economic Perspectives 29 (3): 99-120.

Carrier, James G., and Don Kalb, eds. 2015. Anthropologies of class: Power, practice, and inequality. Cambridge: Cambridge University Press.

Chowdhury, Rashedur. 2017a. "Rana Plaza fieldwork and academic anxiety: Some reflections." Journal of Management Studies 54 (7): 1111-1117.

Chowdhury, Rashedur. 2017b. "The Rana Plaza disaster and the complicit behavior of elite NGOs." Organization 24 (6): 938-949.

Davies, William. 2014. The limits of neoliberalism. London: SAGE.

Davis, Kevin E., Benedict Kingsbury, and Sally Engle Merry. 2012. "Indicators as a technology of global governance." Law and Society Review 46 (1): 71-104.

Dey, Soma, and Palash Basak. 2017. "Out of the shadows: Women and wage struggle in the RMG industry of Bangladesh." Asian Journal of Women's Studies 23 (2): 163-182.
Dreze, Jean, and Amartya Sen. 2013. An uncertain glory: India and its contradictions. London: Allen Lane.

Feldman, Shelley. 2009. "Historicizing garment manufacturing in Bangladesh: Gender, generation, and new regulatory regimes." Journal of International Women's Studies 11 (1): 268-288.

Felski, Rita. 2015. The limits of critique. Chicago: Chicago University Press.

Ferguson, James. 2006. Global shadows: Africa in the neoliberal world order. Durham, NC: Duke University Press.

Gad, Christopher, Casper Bruun Jensen, and Brit Ross Winthereik. 2015. "Practical ontology." NatureCulture 3 (10): 67-86.

Gardner, Katy. 2008. "Keeping connected: Security, place and social capital in a 'Londoni' village in Sylhet.' Journal of the Royal Anthropological Institute 14 (3): 477-495.

Gardner, Katy. 2012. Discordant development: Global capitalism and the struggle for connection in Bangladesh. London: Pluto Press.

Gilbert, Paul Robert. 2015. "The ranking explosion." Social Anthropology 23 (1): 83-86.

Gilbert, Paul Robert. 2018. "Sovereignty and tragedy in contemporary critiques of Investor-State Dispute Settlement." London Review of International Law 6 (2).

Haque, A. K. M. Masudul. 2002. "Privatisation in Bangladesh: A case of placing the cart before the horse." University of Western Sydney Law Review 6 (1): 124-167.

Holbraad, Martin. 2017. "Critique, risqué: A comment on Didier Fassin." Anthropological Theory 17 (2): 274-278.

Hossain, Naomi. 2017. The aid laboratory. Oxford: Oxford University Press.

Hoyland, Bjorn, Karl Moene, and Fredrik Willumsen. 2012. "The tyranny of international index rankings." Journal of Development Economics 97 (1): 1-14.

James, Deborah. 2011. "The return of the broker: Consensus, hierarchy, and choice in South African land reform." Journal of the Royal Anthropological Institute 17 (2): 318-338.

Jensen, Casper Bruun. 2014. "Experiments in Good Faith \& Hopefulness: Toward a postcritical social science." Common Knowledge 20 (2): 337-362.

Jensen, Casper Bruun, and Brit Ross Winthereik. 2013. Monitoring movements in development 
aid: Recursive partnerships and infrastructures. Cambridge, MA: MIT Press.

Kabeer, Naila. 1991. "Cultural dopes or rational fools? Women and labour supply in the Bangladesh garment industry." European Journal of Development Research 3 (1): 133-160.

Kalb, Don. 2015. "Introduction: Class and the new holism." In Carrier and Kalb 2015: 1-27.

Kibria, Nazli. 1995. "Culture, social class, and income control in the lives of women garment workers in Bangladesh." Gender and Society 9 (3): 289-309.

Klak, Thomas, and Garth Myers. 1997. "The discursive tactics of neoliberal development in small third world countries." Geoforum 28 (2): 133-149.

Kobrin, Stanley J. 1982. Managing political risk assessment: Strategic response to environmental change. Berkeley: University of California Press.

Lai, Karen. 2006. "Imagineering Asian emerging markets: Financial knowledge networks in the fund management industry." Geoforum 37 (4): 627-642.

Lash, Scott. 2002. Critique of information. London: SAGE.

Latour, Bruno. 2004. "Why has critique run out of steam? From matters of fact to matters of concern." Critical Inquiry 30 (2): 225-248.

Latour, Bruno. 2005. Reassembling the social: An introduction to actor-network-theory. Oxford: Oxford University Press.

Lewis, David. 2011. Bangladesh: Politics, economy and civil society. Cambridge: Cambridge University Press.

Lewis, David. 2017. "Organising and representing the poor in a clientelistic democracy: The decline of radical NGOs in Bangladesh." Journal of Development Studies 53 (10): 1545-1567.

Lightfoot, Simon, Emma Mawdsley, and Balázs Szent-Ivány. 2017. "Brexit and UK international development policy.” Political Quarterly 88 (3): 517-524.

Mahmud, Wahiduddin, Sadiq Ahmed, and Sandeep Mahajan. 2010. "Economic reforms, growth, and governance: The political economy aspects of Bangladesh's development surprise." In Leadership and growth, ed. David Brady and Michael Spence, 227-254. Washington, DC: World Bank.

Mannan, Manzurul. 2002. “Bangsha: Islam, history, and the structure of Bengali Muslim descent.” In
Contemporary anthropology: Theory and practice, ed. S. M. Nurul Islam, 243-267. Dhaka: University Press Limited.

Marcus, George E. 1989. “Imagining the whole: Ethnography's contemporary efforts to situate itself." Critique of Anthropology 9 (3): 7-30.

Marcus, George E. 1998. Ethnography through thick and thin. Princeton, NJ: Princeton University Press.

Marcus, George E. 2001. "From rapport under erasure to theatres of complicit reflexivity." Qualitative Inquiry 7 (4): 519-528.

Marcus, George E. 2012. "Classic fieldwork, critique and engaged anthropology into the new century." Anthropological Journal of European Cultures 21 (2): 35-42.

Mawdsley, Emma. 2015. "DFID, the private sector and the re-centring of an economic growth agenda in international development." Global Society 29 (3): 339-358.

Merry, Sally Engle, Kevin Davis, and Benedict Kingsbury. 2015. The quiet power of indicators. Cambridge: Cambridge University Press.

Mosse, David. 2013. "The anthropology of international development." Annual Review of Anthropology 42: 227-246.

Mosse, David. 2015. "Misunderstood, misrepresented, contested? Anthropological knowledge production in question." Focaal 72: 128-137.

Mosse, David, and David Lewis. 2006. "Theoretical approaches to brokerage and translation in development." In Development brokers and translators, ed. David Lewis and David Mosse, 1-26. West Hartford, CT: Kumarian Press.

Mowat, Adrian, and Deanne Gordon. 2007. "Ho Chi Minh Trail to Mexico: Launching the JPMorgan Frontier Five and EM8." JPMorgan Emerging Market Equity Research, 4 April 2007. https:// dripfoundation.files.wordpress.com/2012/11/ frontier-five.pdf.

Muhammad, Anu. 2011. "Wealth and deprivation: Ready-made garments industry in Bangladesh." Economic and Political Weekly 46 (34): 23-27.

Nurruzzaman, Mohammed. 2004. "Neoliberal economic reforms, the rich and the poor in Bangladesh." Journal of Contemporary Asia 34 (1): 33-54.

Perry-Kessaris, Amanda. 2011. "Prepare your indicators: Economics imperialism on the shores of law and development." International Journal of Law in Context 7 (4): 401-421. 
Probyn-Rapsey, Fiona. 2007. "Complicity, critique and methodology." ARIEL 38 (2-3): 65-82.

PRS Group. 2011. Bangladesh country report. East Syracuse, NY: PRS Group.

Rahman, Aminur. 1999. Women and microcredit in rural Bangladesh. Boulder, CO: Westview Press.

Rock, Marilyn. 2003. "The rise of the Bangladesh Independent Garment-Workers' Union (BIGU).” In Organising labour in globalising Asia, ed. Jane Hutchison and Andrew Brown, 28-49. London: Routledge.

Sanders, Mark. 2002. Complicities. Durham, NC: Duke University Press.

Schueth, Sam. 2011. "Assembling international competitiveness: The Republic of Georgia, USAID, and the Doing Business project." Economic Geography 87 (1): 51-77.

Sidaway, James, and Michael Pryke. 2000. "The strange geographies of 'emerging markets." Transactions of the Institute of British Geographers 25 (2): 187-201.

Sklair, Leslie. 2000. "The transnational capitalist class and the discourse of globalisation.” Cambridge Review of International Affairs 14 (1): 67-85.

Sklair, Leslie, and Jason Struna. 2013. “The icon project: The transnational capitalist class in action." Globalizations 10 (5): 747-763.
Steinmüller, Hans. 2011. “The state of irony." Critique of Anthropology 31 (1): 21-42.

Sunn Bush, Sarah. 2017. "The politics of rating freedom: Ideological affinity, private authority and the Freedom in the World ratings." Perspectives on Politics 15 (3): 711-731.

Tombs, Steve. 2016. “Better regulation': Better for whom?" Centre for Crime and Justice Studies Briefing 14: 1-16.

Wansleben, Leon. 2013. “'Dreaming with BRICs': Innovating the classificatory regimes of international finance." Journal of Cultural Economy 6 (4): 453-471.

Winthereik, Ross, and Caspar Bruun Jensen. 2017. "Learning from experiments in optimization: Post-critical perspectives on monitoring and evaluation." Journal of Cultural Economy 10 (3): 251-264.

Yarrow, Thomas. 2008. "Paired opposites: Dualism in development and anthropology." Critique of Anthropology 28 (4): 426-445.

Yarrow, Thomas, and Soumhya Venkatesan. 2012. "Anthropology and development: Critical framings." In Differentiating development: Beyond an anthropology of critique, ed. Soumhya Venkatesan and Thomas Yarrow, 1-20. New York: Berghahn Books. 